\title{
PENGARUH MEDIA PEMBELAJARAN ATRAKTIF ROPIBEL TERHADAP HASIL BELAJAR KOGNITIF PADA MATA PELAJARAN IPS SISWA KELAS IV SDN SINGAPADU KECAMATAN CURUG KOTA SERANG
}

\author{
Ika Evitasari Aris ${ }^{1}$, Sastra Wijaya ${ }^{2}$, Nadia llannur ${ }^{3}$ \\ 1PGSD FKIP Universitas Primagraha, ${ }^{2}$ PGSD FKIP Universitas Primagraha, \\ ${ }^{3} P G S D$ FKIP Universitas Primagraha \\ Alamat e-mail: 1ikaaris.upg@gmail.com, 2sastrawijaya0306@gmail.com , \\ 3nadiaannur97@gmail.com \\ Nomor HP: ${ }^{1087773197810,}{ }^{20} 081808834907,{ }^{30} 089673970491$
}

\begin{abstract}
This study aims to determine the effect of attractive learning media ROPIBEL on the cognitive learning outcomes of fourth grade students of SDN Singapadu, Curug district, Serang city. This type of research is the pre-experimental design with a one-group pretest posttest design. The population was all fourth grade students at SDN Singapadu, Curug District, Serang City. Researchers took a sample of class IV totaling 37 people. The sampling technique uses saturated sampling. Data collection techniques used tests, questionnaires, and documentation. Based on the comparison of the results of the pretest and posttest, namely the ability of the pretest in students with an average learning outcome of 39.45 , which is only 3 out of 37 students who managed to achieve the KKM score while the postest ability in students with an average learning outcome of 71.89 was 34 out of 37 students have succeeded in achieving the KKM score so that they get a percentage value of $91.8 \%$. The data analysis technique used the " $t$ " test. The results of this study were as follows: the results of the " $t$ " test on the pretest and posttest learning outcomes obtained tcount $=-12.108$ while ttable with df 72 was at a significant level of 0.000 . Thus the significance value was 0.000 . $<0.05$ which means that work (H1) in this study is accepted, that is, there is an effect of ROPIBEL attractive learning media on cognitive learning outcomes in social studies subjects at SDN Singapadu, Curug District, Serang City.
\end{abstract}

Keywords: ROPIBEL attractive media and learning outcomes 


\section{ABSTRAK}

Penelitian ini bertujuan untuk mengetahui pengaruh media pembelajaran atraktif ROPIBEL terhadap hasil belajar kognitif siswa kelas IV SDN Singapadu kecamatan curug kota serang. Jenis penelitian yang digunakan yaitu PreExperimental Design dengan bentuk desain one-group pretest posttest design. Populasinya adalah seluruh siswa kelas IV di SDN Singapadu Kecamatan Curug Kota Serang. Peneliti mengambil sampel kelas IV berjumlah 37 orang. Teknik pengambilan sampel memakai sampling jenuh. Teknik pengumpulan data menggunakan tes, angket, dan dokumentasi. Berdasarkan perbandingan hasil pretest dan postest yaitu kemampuan pretest pada siswa dengan rata-rata hasil belajar 39,45 yaitu hanya 3 dari 37 siswa yang berhasil mencapai nilai KKM sedangkan kemampuan postest pada siswa dengan rata-rata hasil belajar 71,89 yaitu sebanyak 34 dari 37 siswa telah berhasil mencapai nilai KKM sehingga mendapatkan nilai presentase 91,8 \%. Teknik analisis data menggunakan uji "t". Hasil dari penelitian ini adalah sebagai berikut: hasil pengujian uji "t" terhadap hasil belajar pretest dan posttest diperoleh thitung $=-12.108$ sedangkan tabel dengan df 72 pada taraf signifikan yaitu 0,000. Dengan demikian nilai signifikasi $0.000<0.05$ yang berarti kerja $\left(\mathrm{H}_{1}\right)$ dalam penelitian ini diterima, yaitu terdapat pengaruh media pembelajaran atraktif ROPIBEL terhadap hasil belajar kognitif pada mata pelajaran IPS siswa di SDN Singapadu Kecamatan Curug Kota Serang.

Kata Kunci: Media atraktif ROPIBEL dan Hasil Belajar

\section{A. Pendahuluan}

Proses kegiatan pembelajaran yang berjalan baik dan menyenangkan berdampak positif bagi perkembangan pikiran peserta didik yang secara aktif dapat membangun pengetahuan baru atau merevisi pengetahuan yang sudah peserta didik miliki. Salah satu hal yang mendukung proses pembelajaran yang menyenangkan tersebut adalah penggunaan media pembelajaran yang tepat. namun melihat perkembangan kualitas pendidikan hari ini, tidak semua sekolah dasar di Indonesia memiliki fasiltas sarana dan prasarana yang memadai. Masih banyak sekolah dasar di berbagai daerah yang masih kekurangan fasilitas sarana dan prasarana untuk membantu proses pembelajaran. Seperti halnya yang terjadi di SDN Singapadu Kecamatan Curug pembelajaran seringkali dilakukan dengan metode yang monoton dan menggunakan media pembelajaran yang kurang menarik minat siswa sehingga membuat peserta didik di sekolah tersebut terkadang sulit untuk bisa memahami pelajaran yang disampaikan guru. Hal tersebut dibuktikan dengan hasil 
belajar peserta didik yang masih di bawah nilai KKM yaitu 60. Maka dari itu, dibutuhkan adanya media pembelajaran yang menarik dan dapat mempermudah siswa untuk memahami pembelajaran khususnya pada materi keanekaragaman sosial, ekonomi, budaya, etnis, dan agama.

Peneliti memilih untuk mencoba menggunakan media pembelajaran ROPIBEL (Roda Pintar Belajar) yaitu media yang berbentuk roda dengan beragam warna dan materi di bagian sisi rodanya. Media tersebut digunakan dengan cara diputar. Materi yang terpilih saat roda berhenti tepat di posisi jarum roda maka materi tersebutlah yang akan dimainkan oleh siswa dan guru saat proses pembelajaran berlangsung. Media tersebut dapat dibuat dengan desain yang menarik melalui pemberian warna yang beragam dan dibungkus dengan games sehingga diharapakan dengan penggunaan media tersebut peserta didik semakin bersemangat belajar dan mudah memahami materi yang diajarkan sehingga dapat meningkatkan hasil belajar kognitif peserta didik.

Ranah kognitif adalah ranah yang mencakup kegiatan mental(otak). Menurut Benjamin S.
Bloom kembali, terdapat enam tingkatan penilaian pada ranah kognitif, yaitu level pengetahuan, pemahaman, penerapan, analisis, sintesis, dan evaluasi. Kedua aspek pertama disebut kognitif tingkat rendah dan keempat aspek berikutnya termasuk kognitif tingkat tinggi.

Menurut Fiteriani Ida dan Baharudin (2017: 14) tingkatan hasil belajar ranah kognitif yang cocok digunaan di SD/MI ialah pengetahuan, pemahaman, dan penerapan. Ketiga ranah tersebut menjadi objek penilaian hasil belajar. Di antara tiga ranah tersebut ranah kognitiflah yang paling banyak yang dinilai oleh guru di sekolah karena berkaitan dengan kemampuan para siswa dalam menguasai isi bahan pengajaran. Umumnya, penilaian diperoleh melalui tes yang diberikan pada setiap akhir pembelajaran. Nilai yang diperoleh siswa menjadi acuan untuk melihat penguasaan siswa dalam menerima materi pelajaran.

Pembelajaran dapat berjalan secara efektif jika proses belajar dapat berjalan lancar, terarah, dan sesuai dengan tujuan pembelajaran. Kriteria proses belajar mengajar yang efektif meliputi, 1) Mampu 
mengembangkan

konsep

generalisasi serta mampu mengubah bahan ajar yang abstrak menjadi jelas dan nyata, 2) Mampu melayani gaya belajar dan kecepatan belajar peserta didik yang berbeda-beda, 3) Mampu melayani perkembangan belajar peserta didik yang berbedabeda, 4) Melibatkan peserta didik secara aktif dalam pengajaran sehingga proses belajar mengajar mampu mencapai tujuan sesuai dengan program yang telah ditetapkan (Widyastuti Erawati, 2015: 53).

Dengan penggunaan media ROPIBEL diharpakan peserta didik dapat terlibat secara aktif dan mudah memahami materi yang diajarkan sehingga proses belajar mengajar mampu mencapai tujuan sesuai dengan program yang telah ditetapkan.

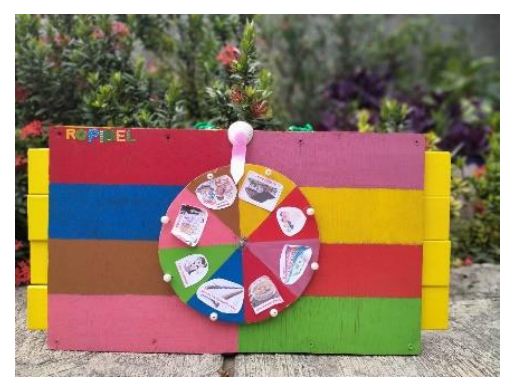

Gambar 1. ROPIBEL bagian Depan

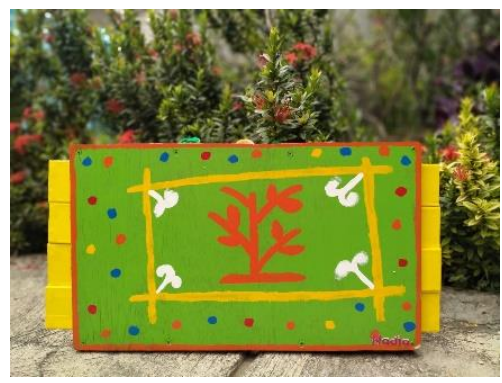

Gambar2. ROPIBEL bagian belakang

Media pembelajaran ROPIBEL (Roda Pintar Belajar) ini sebenarnya berasal dari permainan roulette yang merupakan sebuah permainan casino dan berasal dari bahasa Prancis yang memiliki arti Roda Kecil. Dalam permainan roulette pemain akan memasang taruhan untuk 1 angka ataupun banyak angka ataupun tipe taruhan yang lainnya. Dalam permainan ini roda akan diputar dan bola dilempar ke dalam untuk mengetahui angka dan nomor pemenang. Ketika bola tersebut sudah menetap dalam 1 angka, maka angka dan warna yang menetap yang akan dijadikan penentu kemenangan.

ROPIBEL menjadi salah satu media pembelajaran tematik yang merupakan media visual berbentuk permainan. Melihat di dalam kelas peserta didik lebih senang bermain, media ini dapat memenuhi kebutuhan peserta didik karena didesain menarik dengan permainan dan warna-warna didalamnya. Media ini 
dapat diputar, dilepas dan ditulisi apa saja yang kita inginkan untuk dimasukkan kedalam mika. Media ini dapat digunakan disemua kelas dan pembelajaran apa saja.

Materi yang terdapat pada media ROPIBEL ini disesuaikan dengan materi yang ada di dalam kurikulum 2013 Kelas IV Mata Pelajaran IPS yang mendiskusikan mengenai keragaman budaya Indonesia. Media ini dapat meningkatkan konsentrasi peserta didik dan mengubah cara belajar peserta didik biasanya mempelajari materi melalui buku dan papan tulis beralih pada sebuah media yang menarik minat belajar peserta didik karena dibentuk dengan permainan. Media ROPIBEL dapat dioperasikan secara mandiri ataupun berkelompok dan dapat digunakan untuk media kompetisi dalam pembelajaran.

Cara penggunaannya media pembelajaran atraktif ROPOBEL yaitu, 1) Putar roda yang sudah tersedia dengan poin materi, 2) Tunggu sampai roda berhenti, 3) Mainkan poin materi yang terpilih oleh jarum roda saat roda berhenti berputar dengan cara menjawab pertanyaan atau membahas pernyataan yang tepilih.

\section{B. Metode Penelitian}

Metode penelitian yang digunakan dalam penelitian ini adalah Pre-Experimental Designs. Dalam model desain penelitian ini, kelompok tidak diambil secara acak atau pasangan, juga tidak ada kelompok pembanding, tetapi diberi tes awal dan tes akhir di samping perlakuan (Sukmadinata, N,S, 2011: 208).

Desain penelitian yang digunakan dalam penelitian ini berupa one-group pretest posttest design. Pada desain ini terdapat pretest sebelum diberi perlakuan. Dengan demikan hasil perlakuan dapat diketahui lebih akurat, karena dapat membandingkan dengan keadaan sebelum diberi perlakuan. Desain penelitian dapat dilihat pada tabel di bawah ini.

\begin{tabular}{|lll|}
\hline $\mathrm{O}_{1}$ & $\mathrm{X}$ & $\mathrm{O}_{2}$ \\
\hline
\end{tabular}

Tabel 1. Desain Penelitian

Sumber: Sukmadinata, N,S (2011) Keterangan :

01 : Nilai pre-test (sebelum diberi perlakuan)

$\mathrm{O} 2$ : Nilai post-test (setelah diberi perlakuan) 


$$
\text { X : Treatment }
$$

(penggunaan media

pembelajaran atraktif

ROPIBEL)

Peneliti menggunakan metode eksperimen yang bertujuan untuk mengetahui pengaruh dari suatu perlakuan (treatment) yaitu pengaruh media pembelajaran atraktif ROPIBEL terhadap hasil belajar kognitif mata pelajaran IPS pada materi keanearagaman budaya di Indonesia. Populasi pada penelitian ini yaitu siswa SDN Singapadu Kecamatan Curug Kota Serang kelas IV semester ganjil tahun ajaran 20202021 dengan jumlah 37 anak, dengan sampel sama yaitu 37 siswa.

Teknik pengumpulan data yang digunakan dalam penelitian ini adalah tes berupa soal piliham ganda dengan jumlah 10 soal, non tes berupa angket pelaksanaan pembelajaran ROPIBEL dan Dokumentasi.

\section{C.Hasil Penelitian dan Pembahasan}

Hasil belajar merupakan bagian terpenting dalam pembelajaran, hasil belajar siswa pada hakikatnya adalah perubahan tingkah laku yang terjadi melalui proses pembelajaran perubahan tingkah laku tersebut berupa kemampuan-kemampuan siswa setelah aktifikatas belajar yang menjadi hasil perolehan belajar.

Penelitian ini dilakukan di SDN Singapadu Kecamatan Curug Kota Serang. Teknik yang digunakan untuk mengumpulkan data-data ialah dengan menggunakan tes yaitu berupa soal pilihan ganda berjumlah 10 butir. Soal dibuat berdasarkan kurikulum yang telah ditetapkan di sekolah kemudian digunakan untuk pretest dan postest. Pretest yaitu soal diberikan kepada siswa sebelum mereka melaksanakan proses pembelajaran sedangkan postest adalah soal diberikan kepada siswa setelah mereka melaksanakan proses pembelajaran dengan menggunakan media pembelajaran atraktif ROPIBEL.

Teknik kedua yang digunakan ialah angket yang disusun sesuai dengan aspek yang dibutuhkan untuk mengetahui situasi dan kondisi siswa saat menggunakan media

pembelajaran atraktif ROPIBEL dalam proses pembelajaran di kelas juga untuk memperoleh pendapat dari masing-masing siswa terhadap penggunaan media pembelajaran atraktif ROPIBEL sehingga peneliti 
dapat menggunakan data tersebut sebagai pendukung dalam penelitian ini.

Hasil penelitian yang didapat dari pengelolaan data angket yaitu memperoleh nilai rata-rata 79,6 yang berarti masuk ke dalam kelompok Setuju (S). Bila dilihat dari frekuensi terdapat 17 (45,9 \%) siswa yang sangat menyetujui dan 20 (54 \%) siswa menyetujui tentang penggunaan media atraktif ROPIBEL dalam pembelajaran IPS.

Tabel 2. Hasil Angket (Kuisioner)

\begin{tabular}{|c|c|c|c|c|}
\hline No & $\begin{array}{c}\text { Konversi } \\
\text { Nilai }\end{array}$ & Klasifikasi & $\begin{array}{l}\text { Jumlah } \\
\text { Siswa }\end{array}$ & $\begin{array}{c}\text { Presen } \\
\text { tase }\end{array}$ \\
\hline 1 & $81-100$ & $\begin{array}{c}\text { Sangat } \\
\text { Setuju } \\
\text { (SS) }\end{array}$ & 17 & $45,9 \%$ \\
\hline 2 & $61-80$ & Setuju (S) & 20 & $54 \%$ \\
\hline 3 & $41-60$ & $\begin{array}{c}\text { Ragu- } \\
\text { Ragu (R) }\end{array}$ & - & - \\
\hline 4 & $21-40$ & $\begin{array}{c}\text { Tidak } \\
\text { Setuju } \\
\text { (TS) }\end{array}$ & - & - \\
\hline 5 & $0-20$ & $\begin{array}{c}\text { Sangat } \\
\text { Tidak } \\
\text { Setuju } \\
\text { (SS) }\end{array}$ & - & - \\
\hline
\end{tabular}

Sumber : Wicaksono, A.S, Penilaian

Pembelajaran, 216 (2018)

Peneliti menggunakan media pembelajaran atraktif ROPIBEL yaitu Roda Pintar Belajar yang digunakan dengan cara memutar bagian rodanya sampai jarum yang ada pada roda berhenti di salah satu poin materi berwarna yang sudah dicantumkan, kemudian siswa bisa membuka kotak sesuai warna yang terpilih oleh jarum roda dan menjawab soal yang ada di dalamnya.

Berdasarkan data penelitian yang telah dianalisis pada tanggal 13 Juli dan 29 Agustus 2020, maka dapat diketahui dengan membandingkan nilai pretest dan postest yang sudah dilakukan. Sehingga diperoleh kemampuan pretest pada siswa dengan rata-rata hasil belajar yaitu 39,45 dan kemampuan postest pada siswa dengan rata-rata hasil belajar yaitu 71,89 . Bila dilihat dari frekuensi hasil belajar IPS setelah pretest terdapat 3 siswa di kelompok cukup (8,1\%) dan 34 Siswa di kelompok perlu bimbingan (91,8\%). Sedangkan pada hasil belajar IPS setelah postest terdapat 5 siswa di kelompok sangat baik (13,5\%), 10 Siswa di kelompok baik (27\%), 19 Siswa di kelompok cukup (51\%), dan 3 siswa di kelompok perlu bimbingan $(8,1 \%)$. 
Tabel 3. Hasil Pretest

\begin{tabular}{ccccc}
\hline No & $\begin{array}{c}\text { Konversi } \\
\text { Nilai }\end{array}$ & Klasifikasi & $\begin{array}{c}\text { Jumlah } \\
\text { Siswa }\end{array}$ & $\begin{array}{c}\text { Presen } \\
\text { tase }\end{array}$ \\
\hline $\mathbf{1}$ & $87-100$ & $\begin{array}{c}\text { Sangat } \\
\text { Baik (A) }\end{array}$ & - & - \\
\hline $\mathbf{2}$ & $73-86$ & Baik (B) & - & - \\
\hline $\mathbf{3}$ & $60-72$ & Cukup (C) & 3 & $8.1 \%$ \\
\hline $\mathbf{4}$ & $0-59$ & $\begin{array}{c}\text { Perlu } \\
\text { Bimbingan } \\
\text { (D) }\end{array}$ & 34 & $91,8 \%$ \\
& & & \\
\hline
\end{tabular}

Sumber : Kementerian Pendidikan dan Kebudayaan, 47 (2016)

Tabel 4. Hasil Postest pembelajaran di kelas, selain itu juga terdapat siswa yang tidak sarapan sebelum berangkat ke sekolah sehingga rasa lapar yang timbul ketika pembelajaran berlangsung membuat anak tidak fokus dalam memperhatikan guru di kelas serta terdapat karakter siswa yang berbeda-beda di kelas, sehingga bagi siswa yang memiliki gaya belajar psikomotorik yaitu gaya belajar yang membutuhkan banyak gerak ketika No Konversi Klasifikasi Jumlah Presentase proses pembelajaran dalam artian Nilai Siswa lain yaitu siswa yang aktif bergerak $1 \quad 87-100 \quad \begin{gathered}\text { Sangat } \\ \text { Baik (A) }\end{gathered} \quad 5 \quad 13,5 \%$ dan tidak mau diam di kelas

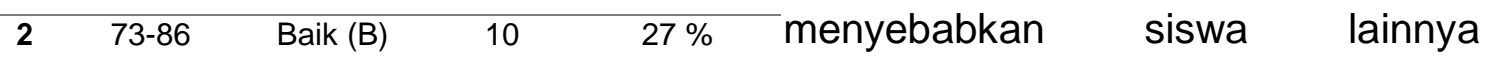

$3 \quad 60-72 \quad$ Cukup $(\mathrm{C}) \quad 19 \quad 51 \% \quad$ terganggu saat sedang berusaha
$4 \quad 0-59 \quad$ Perlu $\quad 3 \quad 8,1 \%$ Bimbingan

(D)

Sumber : Kementerian Pendidikan dan Kebudayaan, 47 (2016)

Berdasarkan perbandingan hasil pretest dan postest yaitu kemampuan pretest pada siswa dengan rata-rata hasil belajar yaitu 39,45 hal ini dikarenakan beberapa faktor yaitu tidak adanya media belajar menarik yang digunakan saat pembelajaran sedangkan faktor pendukung lainnya yaitu kurangnya minat siswa terhadap semangat belajar sehingga mengurangi tingkat fokus anak dalam melaksanakan untuk fokus dalam pembelajaran.
Sedangkan

kemampuan postest pada siswa dengan rata-rata hasil belajar yaitu 71,89 setelah melakukan pembelajaran dengan menggunakan media atraktif ROPIBEL hal ini disebabkan karena media tersebut memiliki beragam warna sehingga dapat menarik perhatian siswa saat proses pembelajaran berlangsung, selain itu media tersebut juga digunakan dengan cara dimainkan yaitu dengan memutar roda dan menunggu sampai jarum media berhenti di salah satu 
poin materi yang tercantum sehingga membuat siswa semakin penasaran untuk menunggu poin yang terpilih, hal ini membuat siswa lebih bersemangat saat proses pembelajaran IPS berlangsung, dengan begitu memungkinkan dapat membuat anak yang tidak semangat dan yang berkarakter gaya belajar psikomotorik menjadi lebih tertarik dan fokus untuk mengikuti pembelajaran. Selain itu, media ROPIBEL ini juga memiliki kelebihan lainnya yaitu dapat digunakan di semua mata pelajaran karena sifatnya yang umum dan poin-poin materi dapat disesuaikan dengan materi yang diajar.

Berdasarkan hasil pretest didapat 5 siswa mendapatkan nilai 20, 7 siswa mendapatkan nilai 30 , 13 siswa mendapatkan nilai 40, 9 siswa mendapatkan nilai 50 , dan 3 siswa mendapatkan nilai 60 . Dengan demikian, dari 37 siswa kelas IV SDN Singapadu terdapat 3 siswa yang sudah mencapai nilai KKM dengan kata lain sebanyak 34 siswa belum mencapai nilai KKM, sedangkan pada hasil postest didapat 3 siswa mendapatkan nilai 50,7 siswa mendapatkan nilai 60, 12 siswa mendapatkan nilai 70, 10 siswa mendapatkan nilai 80 , dan 5 siswa mendapatkan nilai 90. Dengan demikian, dari 37 siswa kelas IV SDN Singapadu terdapat 34 siswa yang sudah mencapai nilai KKM sedangkan sebanyak 3 siswa lainnya masih belum mencapai nilai KKM.

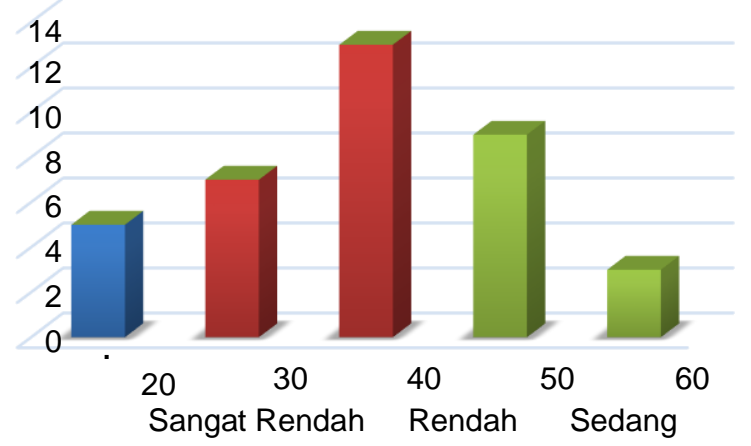

Grafik 1. Tingkatan Hasil Pretest

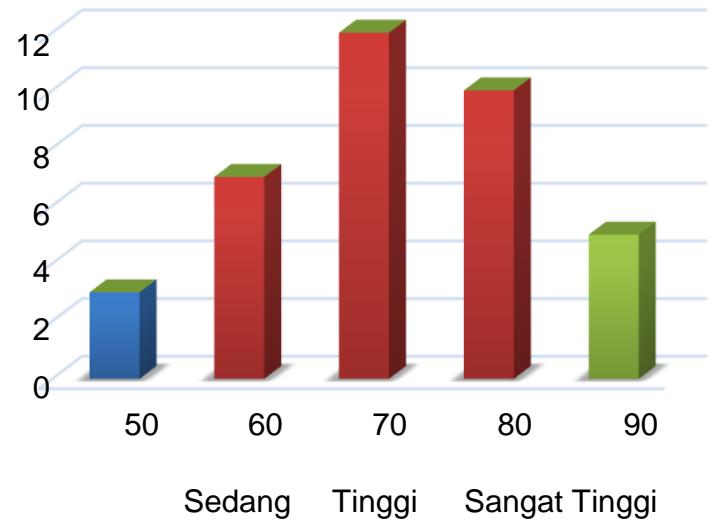

Grafik 2. Tingkatan Hasil Postest

Data tersebut membuktikan bahwa terdapat kenaikan jumlah siswa yang berhasil mendapatkan nilai mencapai nilai KKM setelah diberikannya tindakan yaitu melaksanakan proses pembelajaran IPS dengan menggunakan media atraktif ROPIBEL. Dari 34 siswa yang 
belum mencapai nilai KKM terdapat 3 siswa yang mencapai nilai KKM kemudian setelah dilakukannya tindakan berubah menjadi sebaliknya, yaitu 34 siswa berhasil mencapai nilai KKM sedangkan 3 siswa lainnya masih di bawah nilai KKM. Dapat dikatakan bahwa terdapat pengaruh media pembelajaran atraktif ROPIBEL terhadap mata pelajaran IPS pada materi Keberagaman Budaya di Indonesia siswa Kelas IV SDN Singapadu Kecamatan Curug Kota Serang sebanyak $91.8 \%$.

Untuk lebih membuktikannya dilakukan uji "t" berdasarkan dari hasil pengujian uji "t" yang dilakukan,

Tabel 5. Hasil Uji “t”"

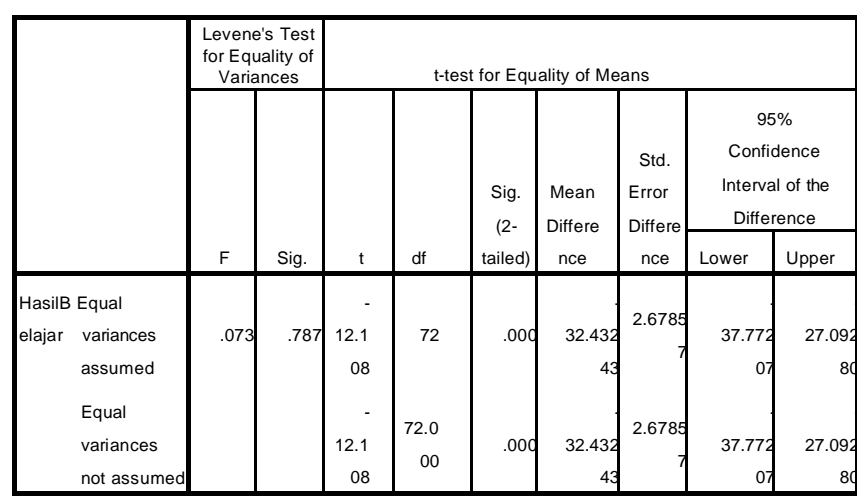

Diperoleh thitung $=-12.108$ sedangkan ttabel dengan df 72 pada taraf signifikan yaitu 0,000 . Dengan demikian nilai signifikasi $0.000<0.05$ yang berarti kerja $(\mathrm{H} 1)$ dalam penelitian ini diterima, yaitu terdapat pengaruh media pembelajaran atraktif ROPIBEL terhadap hasil belajar kognitif pada mata pelajaran IPS siswa di SDN Singapadu Kecamatan Curug Kota Serang

\section{E. Kesimpulan}

Berdasarkan hasil pretest diperoleh kemampuan pretest pada siswa dengan rata-rata hasil belajar yaitu 39,45 sedangkan diperoleh kemampuan postest pada siswa dengan rata-rata hasil belajar yaitu 71,89 . Untuk lebih membuktikannya dilakukan uji " $\mathrm{t}$ " berdasarkan dari hasil pengujian uji " $\mathrm{t}$ " yang dilakukan, diperoleh thitung $=-12.108$ sedangkan ttabel dengan df 72 pada taraf signifikan yaitu 0,000 . Dengan demikian nilai signifikasi $0.000<0.05$ yang berarti kerja (H1) dalam penelitian ini diterima, yaitu terdapat pengaruh media pembelajaran atraktif ROPIBEL terhadap hasil belajar kognitif pada mata pelajaran IPS siswa di SDN Singapadu Kecamatan Curug Kota Serang sebanyak $91.8 \%$. 


\section{DAFTAR PUSTAKA}

\section{Buku :}

Dananjaya, Utomo.2017. Media Pembelajaran Aktif. Bandung. Nuansa Cendekia

Nursalam. 2016. Strategi Belajar Mengajar IPS. Situbondo. CV Garuda Mas Sejahtera

Pramesti, Getut. 2017. Statistika Penelitian dengan SPSS 24. Jakarta. PT Elex Media Komputindo Kompas Gramedia

Rawambaku, Hendrik. 2015. Metodologi Penelitian Pendidikan. Jakarta. Penerbit Libri PT. BPK Gunung Mulia

Riduan. 2010. Dasar-Dasar Statistika. Bandung. Alfabeta

Rojuli, Subkhan. 2016. Strategi Pembelajaran Pendidikan IPS. Surabaya. CV. Garuda Mas Sejahterap

Sari, R. F. 2017. Hubungan Pengetahuan Guru Tentang Manajemen Pembelajaran dengan Kinerja Guru di MTS Negeri 2 Medan. Vol. 1. No. 1. ISSN 3459-2461

Satrianawati. 2018. Media dan Sumber Belajar. Yogyakarta. Deepublish (Grup Penerbitan CV Budi Utama)
Soenarjo, R.J dan Ade Munajat. 2009. IImu Pengetahuan Sosial untuk $S D$ dan MI Kelas IV. Jakarta. Pusat Perbukuan Departemen Pendidikan Nasional

Suhada, H. Idad. 2017. Konsep Dasar IPS. Bandung. PT. Remaja Rosdakarya

Sukmadinata, N. S. 2011. Metode Penelitian Pendidikan. Bandung. PT. Remaja Rosda Karya.

Sugiyono. 2017. Metode Penelitian Kuantitatif, Kualitatif, dan $R$ \& $D$. Bandung. Alfabeta

Suryani $N$, Setiawan $A$, dan Putria A. 2018. Media Pembelajaran Inovatif dan Pengembangannya. Bandung. PT. Remaja Rosdakarya Offset

Wahidmurni. 2017. Metodologi Pembelajaran IPS (Pengembangan Standar Proses Pembelajaran IPS di Sekolah/Madrasah).

Yogyakarta. Ar Ruzz Media

Whitehead, Alfred North. 2018. Tujuan Pendidikan Esensi dan Aspek-Aspek Filosofis. Bandung. Nuansa Cendekia

Wicaksono, A.S. 2018. Penilaian Pembelajaran. Yogyakarta. Universitas Negeri Yogyakarta 
Widaryat, Wowon. 2016. Panduan Penilaian SD. Jakarta. Kementerian Pendidikan dan Kebudayaan

\section{Artikel in Press :}

Raharjo, Sahid. Cara Melakukan Uji Homogenitas dengan SPSS Beserta Contoh Lengkap. 10 April 2020.

https://www.spssindonesi a.com/2 014/02/ujihomogenitas-denganspss.html

Raharjo, Sahid. Cara Melakukan Uji Normalitas Kolomogrov Sminrnov dengan SPSS Beserta Contoh Lengkap. 10 April 2020.

https://www.spssindonesi a.com/2 014/01/uiinormalitas- kolmogorovsmirnov-spss.html

\section{Jurnal :}

Fiteriani I, dan Baharudin. 2017. Analisis Perbedaan Hasil Belajar Kognitif Menggunakan Metode Pembelajaran Kooperatif yang Berkombinasi pada Materi IPA di MIN Lampung. Vol. 4, No. 2 : 2355-1925

Widyastuti Erawati. 2015. Penggunaan ROPITA (Roulette Pintar) untuk Meningkatkan

Kemampuan

Menceritakan

Pengalaman pada Siswa
Tunarungu, Vol. 2, No. 3 : 51-63 